\title{
Relative Access to Credit, Relative Wealth and FDI: Firm-Level Evidence from Japanese FDI into the United States
}

\author{
Joseph D. Alba \\ Nanyang Technological University \\ Peiming Wang \\ Auckland University of Technology \\ Woon-Yee Ho \\ Nanyang Technological University
}

\begin{abstract}
We use data on 317 Japanese firms to examine the effect of relative access to credit and relative wealth on the Japanese firm's rate of foreign direct investment (FDI) in the United States. Using the zero-inflated negative binomial model, we find that multiple rating downgrades of a firm's main bank significantly affected the Japanese firm's rate of FDI in the United States. This result holds for firms with the highest $20 \%$ of bonds-to-liabilities ratio indicating that banking problems in Japan affected even firms who could have financed their FDI with bonds. We also find that the firm's rate of FDI is affected by the firm's relative wealth.
\end{abstract}

- JEL classification: F23, C35, G21

- Keywords: Relative access to credit, Relative wealth, Exchange rate,

\footnotetext{
*Corresponding address: Joseph D. Alba, S3-B2B-56, Division of Economics, School of Humanities and Social Sciences, Nanyang Technological University, Nanyang Avenue, Singapore 639798, phone: (65) 67906234, fax: (65) 6794-2830, E-mail: ajoalba@ntu.edu.sg, Peiming Wang, phone: (64) 99219999 Extn: 5393, fax: (64) 9 9219940, E-mail: peiming.wang@aut.ac.nz, Woon-Yee Ho, phone: (65) 67904285 , fax: (65) 6794 2830, E-mail: ewyho@ntu.edu.sg

(2007-Center for International Economics, Sejong Institution, All Rights Reserved.
} 
Zero-inflated Poisson (ZIP), Zero-inflated negative binomial (ZINB)

\section{Introduction}

Before the 1980s, theories on foreign direct investments (FDI) primarily focus on industrial organization motives in explaining FDI. ${ }^{1}$ Although these traditional theories explain the patterns of FDI for particular industries, they cannot fully explain the large fluctuations of FDI inflows into the United States of Japanese firms. As shown in Panel A of Figure 1, the number of FDI projects of Japanese firms in the United States began to increase in the late 1970s but surged from 1983 until 1987. The dramatic surge in Japanese FDI was followed by a large decline in Japanese FDI projects in the United States until 1993.

The surge in Japanese FDI may be related to the large depreciation of the US dollar in the 1980s. This is observed in Figure 1, which shows that both the large increases in the total and the share of the number of Japanese FDI projects in the United States were preceded by the large depreciation of the US dollar - Japanese yen real exchange rate. To explain the link between US FDI inflows and real exchange rates, Froot and Stein (1991) assume asymmetric information on assets' payoffs. $^{2}$ They argue that owners of assets know the assets' realized payoffs without cost but external creditors can verify the payoffs only with costs. This makes external finance more expensive than internal finance so foreign firms who wish to bid for US assets must raise most of their funds internally. Because internal funds of foreign firms are denominated in foreign currency, a depreciation of the US dollar increases foreign firms' relative wealth and allows them to bid more aggressively for US assets. Hence, a depreciation of the US dollar increases FDI into the United States.

Froot and Stein's proposition seems to be supported by the data in the 1980s and

${ }^{1}$ Caves (1971) and Graham and Krugman (1995) review theories based on the industrial-organization motives for FDI.

${ }^{2}$ Assuming segmented goods markets and limited access of US firms in foreign markets, Blonigen (1997) develops a model linking exchange rates to the foreign acquisition of a US firm. Foreign firms value more firm-specific assets of a US firm because of the usefulness of US assets in gaining an advantage in foreign markets. When the US dollar depreciates, foreign firms' reservation prices (in foreign currency) increase relative to the other US firms' reservation prices (in US dollars) in bidding for US assets. Hence, the depreciation of the US dollar allows foreign firms to outbid US firms for US assets. 
Fig. 1.

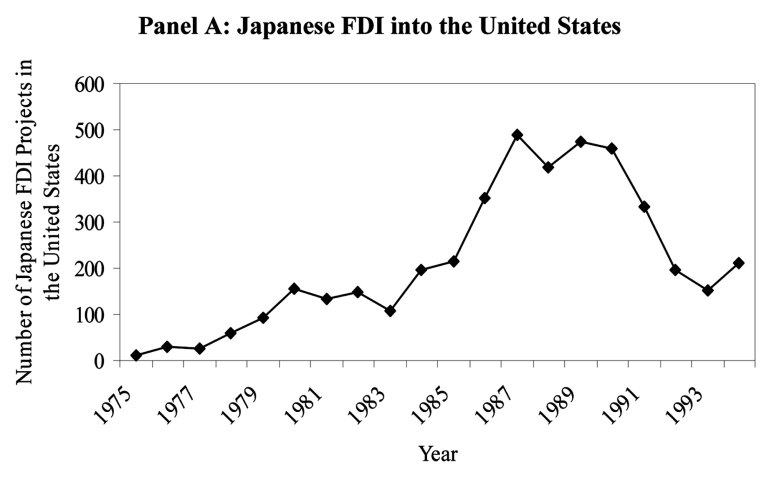

Panel B: Share of Japanese FDI into the United States and the Real US dollar - Japanese yen exchange rate

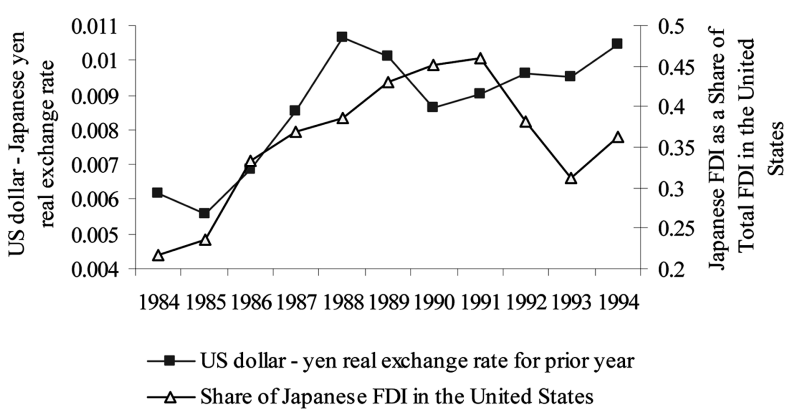

Notes: US dollar - Japanese yen real exchange rate is calculated by multiplying the bilateral US dollar - yen exchange rate by US CPI and dividing by the Japanese CPI. The exchange rate and CPI data are from International Financial Statistics, International Monetary Fund (IMF). The number of Japanese FDI projects is from the United States Department of Commence, International Trade Administration's publication Foreign Direct Investments in the United States: Transactions.

the early 1990s as plotted in Figure 1: the Japanese FDI flows into the United States surged when the US dollar real exchange rate depreciated and it slowed down when the US dollar appreciated. ${ }^{3}$ However, after 1991, Japanese FDI flows in the United States declined sharply despite the depreciation of the US dollar. To explain the sharp decline of Japanese FDI into the United States in the 1990s, Klein, Peek and Rosengren (2002) propose the relative access to credit hypothesis assuming firms have unequal access to external credit. They argue that in the mid1990s, Japanese firms investing in the United States could have been constrained

${ }^{3}$ From the 1980 to 1991, Froot and Stein (1991) and Klein and Rosengren (1994) find evidence linking exchange rates and US FDI. 
by their balance sheet positions as the asset prices collapsed and by the reduction of available credit from their associated banks as the banks' finances weakened. ${ }^{4}$

Klein, Peek and Rosengren (2002) test the relative access to credit hypothesis using two different estimating equations: one equation for data aggregated at the bank-level and another equation for data at the firm level. Firm data consist of 1987 to 1994 FDI to the United States of Japanese firms associated with 11 Japanese banks. Using aggregated data, they ran a linear regression to determine the factors affecting the change in the number of FDI projects of firms associated with each of the 11 banks. They show that the number of FDI projects of the bank's client firms declined with the worsening of the bank's credit rating. Using firm-level data, they use a logit model to determine the factors affecting the probability of a Japanese firm investing in the United States. They show that relative access to credit affects the probability of firms undertaking FDI.

Klein, Peek and Rosengren show the effect of relative access to credit on the change in number of FDI using data aggregated at the bank level. In effect, they examine how the FDI of clients of a typical main bank are affected by financial problems in the main bank. However, their findings may not hold for a typical Japanese firm because a firm may seek alternative financing from another bank or from financial markets. Therefore, it is important to examine the impact of relative access to credit at both the bank level and the firm level.

Klein, Peek and Rosengren deal with the issue of firms having alternative financing in three ways: First, they argue that in Japan, the extensive relationship between firms and their main banks goes beyond bank lending. This means that even large and profitable firms who have no need of bank loans could be affected when their main banks encounter financial problems. ${ }^{5}$

Second, they show using information from the Japan Company Handbook (JCH) that very few firms ever switch banks. Third, they run separate logit regressions of firms with the top $20 \%$ and with the bottom $80 \%$ of bonds-to-liabilities ratios. Contrary to their argument that even large firms may be affected by bank downgrade, they find that the probability of FDI for firms with the top $20 \%$ bondsto-liabilities ratios are not affected by the lower ratings of the firm's main banks. However, the measure of the probability of undertaking FDI is distinct from the

${ }^{4}$ Gibson (1995) examines the effect of bank health in Japan to domestic investment.

${ }^{5}$ Klein Peek and Rosengren note that Japanese firms are dependent on their main banks for functions such as payroll and letters of credit and other functions due to the cross-share holdings with its main bank. We elaborate on the main-bank and firm relationship in Japan in the next section. 
extent or the actual rate of the firm's FDI. While certain factors may make a firm more likely to undertake FDI, a firm with a high probability of undertaking FDI may eventually not undertake FDI. Therefore, it is worthwhile to examine the effect of relative access to credit on both the probability of a firm undertaking FDI and the actual rate of the firm's FDI.

We investigate the factors that affect the rate of FDI of a firm by examining both the factors associated with the conditional rate of FDI of a Japanese firm likely to have the intention to invest in the United States and the factors associated with the probability that a Japanese firm has the intention to invest in the United States. We consider 317 Japanese firms with at least one FDI in the United States from 1987 to $1994 .{ }^{6}$ The firms are listed in the first section of the Japan Company Handbook ( JCH) and associated with one of the 11 Japanese banks identified by Klein, Peek and Rosengren (2002). From the 317 firms over a period 1987 to 1994, we construct a data set with 2,057 observations in which 627 observations have positive numbers of FDI projects that range from one to seventeen and 1430 observations have zeros. ${ }^{7}$

Our sample of FDI projects has a mean of 0.52 and a variance of 1.28. Because the sample variance significantly exceeds the sample mean, it suggests that the probability distribution of the number of FDI projects is more likely a negative binomial instead of a Poisson distribution. Because our sample has a large number of zeros, the excess zeros suggest that the FDI data contain a sample mixture exhibiting two different behavioral traits. The distinction could arise from the different behavior of Japanese firms at any point in time. The first type of behavioral trait belongs to firms with no intention to engage in FDI during a particular period. They will always contribute a zero FDI entry count in the data. The second type of behavioral trait belongs to firms with intention to engage in FDI but their investment plans may not materialize. In the presence of Japanese firms with no intention to engage in FDI for a given period, these firms add additional mass at the zero value resulting in high incidence of zero counts than is

\footnotetext{
${ }^{6}$ We consider the same period as Klein, Peek and Rosengren. The period covered in the study is constrained by data availability. Data on Moody's bank rating begins in 1987 while data on firm level FDI ends in 1994. The United States International Trade Administration (ITA) stopped publishing firm level data on FDI in 1994.

${ }^{7}$ We record that the firm has zero FDI during years when the United States International Trade Administration (ITA) has no record of the firm undertaking FDI. We cannot exclude these zero observations from our sample because this would result in an upward bias in the estimate of the rate of FDI of firms. We explain below a formal way of handling excess zeros in our sample.
} 
consistent with the standard negative binomial regression model. However when we observe a zero FDI entry, it is not at all obvious whether the zero value belongs to a firm with or without intention to engage in FDI. Unless we can distinguish among firms according to their intention to invest in the United States, we would be underestimating the rate of FDI in the United States.

To analyze the firm's rate of FDI, we use the zero-inflated negative binomial (ZINB) model assuming the firm's intention to invest to be a partially observable binary random variable in which the firm either has or has no intention to undertake FDI. ${ }^{8}$ The model estimates the probabilities of the firm's intention to invest in the United States as a logit function based on a vector of determinants. These determinants are similar to those used by Klein, Peek and Rosengren in their logit regressions. Moreover, the model estimates the rate of FDI for a firm with intention to undertake FDI as an exponential function based on firm-level determinants as defined by Klein, Peek and Rosengren. ${ }^{9}$ Note that the rate of FDI for any firm is equal to the rate of FDI for a firm with intention to undertake FDI multiplied by the probability of the firm's intention to invest in the United States. ${ }^{10}$

The ZINB model may be interpreted as two separate stages of the firm's investment process. The first stage occurs at the beginning of an investment period when a particular firm has to decide whether to engage in FDI in the United States. If a firm finds the conditions unfavorable and decides not to invest during a particular period, it is assumed that the firm will have no FDI project at the end of this period. On the other hand, if a firm finds the initial conditions favorable and intends to invest during a particular period, the firm is then at the second stage where it needs to decide the number of FDI projects for the period. However, at the end of this period, the number of FDI projects actually undertaken by the firm is uncertain and may range from zero to any positive number. For example, a firm

\footnotetext{
${ }^{8}$ The intention to invest is only partially observable because we would know that the firm had planned and intended to invest only after it makes the investment. As we explain in the next paragraph, some firms may intend to invest but may eventually decide not to invest. When a firm has no FDI, we cannot observe its intention so we assume that the firm's intention to invest is a partially observable binary random variable. This is formally stated in equation (1).

${ }^{9}$ Klein, Peek and Rosengren aggregated the firm-level determinants at the bank level. They run a regression with the number of FDI and the aggregated variables together with macroeconomic variables.

${ }^{10}$ In contrast, the negative binomial (NB) model does not calculate the probabilities of the firm's intention to undertake FDI in calculating the firm's rate of FDI. Using the NB instead of the ZINB model underestimates the firm's rate of FDI. We would be making incorrect inferences on the firm's rate of FDI. We formally present the ZINB model in Section III.
} 
with intention to engage in FDI could find the conditions to be even more favorable after some interval of time so it undertakes more than one FDI. In contrast, a firm may have the intention to engage in FDI but after some interval of time, it finds that conditions have changed from favorable to unfavorable so it decides not to undertake FDI. In this case, the firm may have the intention to undertake FDI but it may still result in no FDI project at the end of the period. Hence, at the end of a particular period, the number of FDI projects undertaken by a firm with intention to invest is random and is assumed to follow a negative binomial probability distribution.

We consider factors affecting the conditional rate of FDI of a Japanese firm with an intention to undertake FDI such as the change in the financial-health rating of a firm's main bank, and the changes in firm characteristics such as the profitability, firm size and relative wealth. At the same time, we consider factors affecting the probability that a Japanese firm has intention to invest in the United States such as the financial rating of the firm's main bank and firm characteristics such as profitability, relative wealth and firm size. Our measure of relative wealth is at the firm level unlike Klein, Peek and Rosengren who measure relative wealth at the aggregate level. Also unlike Klein, Peek and Rosengren, we exclude the US unemployment rate and Japan job-offers-to-applicant ratio primarily because economic theory does not offer compelling reasons for the inclusion of these variables. Graham and Krugman (1995) note the strong positive correlation between aggregate FDI flows and business cycles in the United States. However, they also note that there is no compelling reason why US assets would be more or less attractive to Japanese investors compared with US investors during economic upturns or downturns. In addition, including these two macroeconomic variables create two potential econometric problems: First, Moulton (1990) finds a bias in standard errors from regressions with aggregate explanatory variables and firmlevel dependent and independent variables. He notes that random disturbances in regressions with micro variables are often correlated within groups such that even low correlation among the macroeconomic variables and the micro variables results in a downward bias in the standard errors of the aggregate variables. Because of the bias in the standard errors, aggregate variables regressed with firm-level variables could show significant results when they should have been insignificant. Second, we find that the two macroeconomic variables and firm-level variables in our study have high and significant correlation. As we discuss in Section IV, we find that these correlations create problems of multicollinearity in the regressions, which 
may lead to incorrect estimates of the regression coefficients and bias their standard errors upwards. Hence, we exclude business cycle variables as regressors.

As in Klein, Peek and Rosengren, we run regressions on the full sample and on sub-samples of firms with the top $20 \%$ and the lowest $80 \%$ of bonds-to-liabilities ratios and of firms with FDI in multiple years. By running regressions on the subsamples of firms, we examine the impact of the financial problems of Japanese banks on the rate of FDI of firms that may have little need of loans and can finance their FDI by issuing bonds. We use the $20 \%$ and $80 \%$ ratios of bonds-to-liabilities for our results to be comparable to those of Klein, Peek and Rosengren.

We find that the change in relative access to credit affects the extent or the rate of a firm's FDI for our full sample and sub-samples of firms with the lowest $80 \%$ of bonds-to-liabilities ratio, firms with the highest $20 \%$ of bonds-to-liabilities and firms that undertake FDI in multiple years. We also find that the change in relative wealth affects the rate of FDI only for a sub-sample of firms with the lowest $80 \%$ of bonds-to-liabilities ratio. In contrast, we find that the probability of a Japanese firm intending to invest in the United States is affected by low bank ratings only for the full sample and the sub-sample of firms with multi-year FDI. Relative wealth also significantly affects the probability that a firm intends to invest in the United States for sub-samples of firms with the highest $20 \%$ of bonds-to-liabilities ratio and firms with FDI in multiple years. These results highlight the importance of distinguishing the extent or actual rate of the firm's FDI from the probability of the firm undertaking FDI.

The paper is organized as follows: in section II, we discuss the firm-level FDI data and the model specification; in section III, we discuss the rationale of the determinants of FDI; in section IV, we discuss the empirical results; and in section $\mathrm{V}$, we discuss the conclusions.

\section{Data on Japanese Firms and Model Specification}

We consider all firms listed in the first section of the Japan Company Handbook (JCH) with at least one FDI in the United States from 1987 to 1994 and with one of the 11 Japanese banks as their main bank. We follow Klein, Peek and Rosengren (2002) who identify the 11 banks as the Industrial Bank of Japan, Dai-Ichi Kangyo Bank, Sakura Bank, Mitsubishi Bank, Fuji Bank, Sumitomo Bank, Sanwa Bank, Tokai Bank, Asahi Bank, Long-Term Credit Bank and Daiwa Bank. One of the 11 banks is the firm's main bank if it is the first bank among reference banks listed in the 
JCH for the firm. From 1987 to 1994, 317 firms in the JCH with at least one FDI in the United States are associated with one of the 11 banks. These firms invested in 94\% of all FDI projects in the United States undertaken by firms associated with the 11 banks.

Klein, Peek and Rosengren focus on the 11 primary or main banks of Japanese firms to examine the impact of reduced access to credit on Japanese firms' FDI. They justify focusing on Japanese firms' main bank rather than considering all of the firms' reference banks by pointing to the special relationship between firms and their main banks in Japan. The main bank among other banks maintains the largest loan share to a firm. According to Sheard (1989), the main bank was the primary source of borrowing for over two-thirds of Japan's 873 non-financial firms listed in the first section of the Tokyo Stock Exchange in 1982. In addition, the main bank is typically a principal shareholder of the firm. The equity holdings of main banks in Japanese firms make information sharing between the main bank and the firm the cornerstone of the main bank system. The firm often consults the main bank on its business plans and provides the bank with regular reports on its performance. This process of information exchange is further formalized by having senior executives of the main bank on the firm's board of directors. The bank's access to the internal decision-making of the firm allows the bank to be informed about the firm and its management at relatively low costs. Because of reduced monitoring costs, firms can receive better terms of credit from its main bank because information on the firm's creditworthiness is already at the bank.

We construct a data set with 2,057 observations for 317 firms from 1987 to 1994. Each observation records the number of FDI projects that a firm undertakes for a given year. We compile the number of FDI projects of the 317 firms over our sample period from the United States International Trade Administration (ITA) publication, "Foreign Direct Investment in the United States: Transactions." We use observations on the number of FDI projects in examining the firm-level Japanese FDI in the United States because $51 \%$ of the FDI projects reported in the ITA publication has missing values on the amounts of FDI projects. ${ }^{11}$

Based on the data compiled from the ITA, 627 observations are non-zeros with each observation varying from one to seventeen FDI projects and with a total of

\footnotetext{
${ }^{11}$ Because of confidentiality agreements with firms, ITA does not report values of FDI projects in $51 \%$ of the observations. We cannot use only the remaining $49 \%$ of the observations because this results in selection bias. Hence, instead of values of FDI projects, we use the number of FDI as our dependent variable. Similarly, Campa (1993), Blonigen (1997), Tomlin (2000), List (2001) and Klein, Peek and Rosengren (2002) use number rather than value of FDI projects from the same ITA data set. Swenson (2004) is the exception but her results could have selection bias.
} 
1,070 FDI projects for 317 firms from 1987 to 1994 . However, it is not every year that the ITA records a firm as having an FDI project. When ITA has no record of a firm having an FDI project for a period, we assume the firm has no FDI project for that period and we enter a zero as our observation for the firm. From a sample size of 2,057 observations, 1,430 observations are zeros, which account for $69.5 \%$ of all the observations. ${ }^{12}$

Even though a firm has no FDI project for a given year, it does not mean that the firm has no intention to invest in the United States for that year. A firm may have the intention to invest but for whatever reason, it does not undertake FDI. Hence, we distinguish among firms according to their intention to invest in the United States by defining a partially observable binary random variable as follows:

$$
D_{i}=\left\{\begin{array}{l}
0 \text { if firm does not intend to invest in the USA; and } \\
1 \text { if firm } \mathrm{i} \text { intends to invest in the USA. }
\end{array}\right.
$$

The probability that firm i does not intend to invest in the United States is given by:

$$
P_{i} \equiv \operatorname{Pr}\left(D_{i}=0\right)=\frac{\exp \left(\tilde{\beta}^{\prime} Z_{i}\right)}{1+\exp \left(\tilde{\beta}^{\prime} Z_{i}\right)} \equiv \operatorname{logit}\left(\tilde{\beta}^{\prime} Z_{i}\right),
$$

where $P_{i}$ is a logit function of a vector of regressors $\left(Z_{i}\right) .1-P_{i}$ is the probability that firm $\mathrm{i}$ intends to invest in the United States.

If firm i does not intend to invest in the United States $\left(D_{i}=0\right)$ for a given year, we assume that it has no FDI project for that year. However, if firm i intends to invest in the United States $\left(D_{i}=1\right)$, we assume that the number of its FDI projects has a negative binomial distribution with a mean of $\lambda_{i}$ and dispersion parameter $\alpha>0$. Thus, the probability of having an observation of a zero FDI project can be stated as:

$\operatorname{Prod}\left[F D I \_\right.$observation $\left.{ }_{i}=F D I_{i}=0\right]=P_{i}+\left(1-P_{i}\right)$ negative binomial $\left(0 ; \lambda_{i}, \alpha\right)$;

and the probability of an observation having a non-zero FDI project is given by: $\operatorname{Prod}\left[F D I \_\right.$observation $\left._{i}=F D I_{i}>0\right]=\left(1-P_{i}\right)$ negative binomial $\left(F D I_{i} ; \lambda_{i}, \alpha\right)$.

\footnotetext{
${ }^{12}$ The frequency distribution of FDI projects for $0,1,2,3,4$, and greater than 5 projects are 1430,422 , $108,38,27$ and 32 observations, respectively.
} 
The mean of the negative binomial distribution $\left(\lambda_{i}\right)$ is the firm i's rate of FDI conditional on the firm with intention to invest, and is an exponential function of the vector of regressors $X_{i}$ :

$$
\lambda_{i}=e^{\beta^{\prime} X_{i}}
$$

For a firm with intention to invest in the United States, the conditional mean and variance of $F D I_{i}$ are given by:

$$
\begin{aligned}
& E\left(F D I_{i} \mid D_{i}=1\right)=\lambda_{i} \text { and } \\
& \operatorname{Var}\left(F D I_{i} \mid D_{i}=1\right)=\lambda_{i}+\alpha \lambda_{i}^{2}, \text { respectively }
\end{aligned}
$$

Equations (6) and (7) indicate that among firms with intention to invest in the United States, the model can account for the extra variation in FDI projects relative to the Poisson distribution. The model is called the zero-inflated negative binomial (ZINB) regression model. The ZINB model reduces to a zero-inflated Poisson (ZIP) model as the limit of $\alpha$ approaches zero. ${ }^{13}$ To determine whether the conditional distribution is Poisson or negative binomial, we use the score test developed by Ridout, Hinde and Demétrio (2001).

Note that the rate of FDI for any firm $\mathrm{i}$ is given by:

$$
E\left(F D I_{i}\right)=\lambda_{i}\left(1-P_{i}\right){ }^{14}
$$

Equation (8) implies that the rate of FDI for any firm is affected both by the conditional rate of FDI for a firm with intention to invest in the United States $\left(\lambda_{i}\right)$ and the probability of a firm with intention to invest in the United States $\left(1-P_{i}\right)$. In other words, given $\left(1-P_{i}\right)$, we can infer the rate of FDI for any firm i from the conditional rate of FDI $\left(\lambda_{i}\right)$.

\footnotetext{
${ }^{13}$ The Poisson and the negative binomial regression models are discussed in Greene (2005). Greene (1994) and Freund, Kniesner, LoSasso (1999) discuss dealing with excess zeros in count data.

${ }^{14}$ Equation (8) can be derived as $E\left(F D I_{i}\right)=E\left(F D I_{I} \mid D_{i}=0\right) \operatorname{Prob}\left(D_{i}=0\right)+E\left(F D I_{I} \mid D_{i}=1\right) \operatorname{Prob}\left(D_{i}\right.$ $=1)$ in which $E\left(F D I_{I} \mid D_{i}=0\right)=0, E\left(F D I_{I} \mid D_{i}=1\right)=\lambda_{i}$ and $\operatorname{Prob}\left(D_{i}=1\right)=1-P_{i}$.
} 


\section{Determinants of FDI}

In equation 2, the regressors in the vector $Z_{i}$ are determinants from Klein, Peek and Rosengren's (2002) logit regression, namely the previous year rating of the firm's main bank and the firm's size, profits and relative wealth. These determinants affect the probability that a Japanese firm has no intention to invest in the United States $\left(P_{i}\right)$ and the probability that a Japanese firm has intention to invest in the United States $\left(1-P_{i}\right)$.

The financial health of the firm's main bank is measured by the rating according to Moody's long-term deposit ratings, which are, from best to worst, Aaa, Aa1, Aa2, Aa3, A1 and A2. ${ }^{15}$ Except for the best rating of Aaa, each Moody's rating is assigned a dummy variable of either one for that rating or zero otherwise. Hence, the coefficient of the dummy variable indicates the impact of the rating of the firm's main bank relative to the best rating of Aaa on the probability that the firm has intention to invest in the United States $\left(1-P_{i}\right)$. In other words, a negative coefficient would show a lower probability that the firm would have the intention to invest in the United States when the firm's main bank has a rating lower than the best rating.

The effect of firm size on $\left(1-P_{i}\right)$ considers the traditional theories' explanation of the impact of firm characteristics on FDI. Among industrial countries, traditional theories explain the importance of firm size in horizontal FDI. Horizontal FDI occurs when Japanese firms invest in the United States to sell the same general line of products that they sell in Japan. To enter the US markets, Japanese firms must incur high fixed costs of gathering information on US markets even though the information may be freely available to US firms. Because of the high fixed costs of undertaking FDI, Japanese firms who are likely to have the intention to invest in the United States are usually large and dominant firms in Japan. These firms dominate Japanese markets with their economies of scale, marketing skills and technological advantages. Large firms also gain additional advantages in FDI because they can internalize licensing or exporting costs. By producing in the United States, large Japanese firms avoid licensing or exporting costs and gain

\footnotetext{
${ }^{15}$ Klein, Peek and Rosengren (2002) summarize Moody's long-term deposit ratings for the 11 banks from 1986 to 1994 (Table 2, page 670) including the lowest rating of A3. In our case, out of 2065 observations, there are only has 8 observations in which a firm's main bank had a rating of A3. Because of the very small number of observations for a rating of $A 3$, the coefficient of the dummy variable for A3 had a very large standard error. Hence, we excluded observations these observations in our analysis.
} 
internalization advantages. These advantages enable large Japanese firms to undertake FDI.$^{16}$ With firm size measured as the logarithm of the inflation-adjusted value of the firm's assets, it would be positively related to $1-P_{i}$.

Consistent with traditional theory, firm profitability could affect $1-P_{i}$. The firm's advantages could result in lower costs and higher sales. Hence, the firm investing in FDI tends to be profitable. With profitability measured as the firm's profit-toasset ratio, it would be positively related to $1-P_{i}$.

1- $P_{i}$ could be determined by relative wealth. Relative wealth is calculated by multiplying the stock price index of the Japanese firm by the nominal US dollaryen exchange rate and dividing by the S\&P 500 index. It captures the effects of exchange rate and relative stock price movements on $1-P_{i}$. Froot and Stein (1991) explain the effects of exchange rates and relative stock prices on FDI by assuming asymmetric information on payoffs of assets. Asymmetric information makes internal finance cheaper than external finance so Japanese firms would have to raise funds internally to bid for assets in the United States. Since Japanese firms must raise funds internally, they can bid a higher price for US assets when their stock prices increase relative to US stock prices and when the US dollar depreciates relative to the Japanese yen. Hence, higher relative wealth increases 1$P_{i}$ so relative wealth is positively related to $1-P_{i}$.

For a firm with intention to invest in the United States, it has the conditional rate of FDI $\left(\lambda_{i}\right)$ determined by the change in the rating of the firm's main bank and the annual changes in the firm's relative wealth, size and profitability. These determinants are included in the ZINB model as regressors in the vector $X_{i}$ of equation 5. As in $1-P_{i}$ and as we argue above, we exclude the business cycle variables among the regressors. ${ }^{17}$

Following Klein, Peek and Rosengren (2002), we examine how the weakness in the firm's main bank affects the rate of FDI using the changes in the Moody's

\footnotetext{
${ }^{16}$ The importance of firm size in FDI is explained in Caves (1971) and in Horst (1972). Both authors note that firm size is an important determinant of FDI.

${ }^{17}$ Klein, Peek and Rosengren (2002) consider the following as determinants of the change in the number of FDI of firms associated with one of the 11 Japanese banks: the change in the Moody's rating of each bank; the change in the sum of profits of firms associated with each bank; and the change in relative wealth measured as the percentage change in the nominal Nikkei stock index minus the percentage change in the US S\&P 500 stock index plus the percentage change in the US dollar-yen exchange rate. They focus on first differences in the variables in order to capture the impact of the changes in these variables - particularly the changes in the financial conditions of banks - on the changes in the pattern of FDI.
} 
ratings of the firm's main bank. We measure these changes using two dummy variables for single downgrade and multiple downgrades in the rating of the firm's main bank. The dummy variable for a single downgrade has a value of one if the rating of a firm's main bank is downgraded by one level in a given year and a value of zero otherwise. The dummy variable for multiple-downgrades has a value of one if the rating of a firm's main bank is downgraded by two or more levels in a given year and a value of zero otherwise. Downgrades in the rating of the firm's main bank should be negatively related to $\lambda_{i}$.

Consistent with our firm-level specification, we include three firm-level variables as determinants of the rate of FDI $\left(\lambda_{i}\right)$ namely, the annual changes in the firm's relative wealth, size and profitability. A higher relative wealth could increase the rate of FDI of Japanese firms with intention to invest in the United States. This follows Froot and Stein's (1991) proposition in which a higher relative wealth allows Japanese firms to bid more aggressively for US assets. Hence, relatively wealth could be positively related to $\lambda_{i}$. We also follow the traditional theories' rationale on the impact of profitability and firm size on FDI. As mentioned above, large and profitable firms usually have both firm-specific and internalization advantages that allow them to undertake FDI. Larger firms should have a higher rate of FDI. Hence, changes in firm size and profitability would be positively related to $\lambda_{i}$.

The data on bank ratings are from Moody's long-term deposit ratings. Data on firm characteristics are from the Pacific-Basin Capital Markets Databases (PACAP). The US dollar-yen exchange rate is from the International Financial Statistics. The S\&P 500 index is from Global Financial Data.

\section{Empirical Results}

As we mentioned above, we should not include the macroeconomic variables representing business cycles of the United States and Japan because it is not justified by economic theory. Nevertheless, we investigate the econometric implications of including business cycle variables in the regressions. First, we test for correlation using the Pearson correlation tests. The results in Table 1 show that the levels and first differences of the US unemployment rate and the Japan joboffers-to-applicants ratio have high and significant correlation with each other and with the levels and first differences of firm-level variables except for firm size. We then run ZIP and ZINB regressions for all firms with the business cycle variables, 
Table 1. Person Correlation Cofficients

\begin{tabular}{|c|c|c|c|c|}
\hline & $\begin{array}{l}\text { US } \\
\text { unemployment } \\
\text { rate }\end{array}$ & $\begin{array}{l}\text { Japan job- } \\
\text { offers-to- } \\
\text { applicants } \\
\text { ratio }\end{array}$ & $\begin{array}{l}\text { Change in US } \\
\text { unemploy- } \\
\text { ment } \\
\text { rate }\end{array}$ & $\begin{array}{l}\text { Change in } \\
\text { Japanese } \\
\text { job-offers-to- } \\
\text { applicants } \\
\text { ratio }\end{array}$ \\
\hline$\overline{\text { Aal }}$ & $-0.209^{* *}$ & $0.378^{* *}$ & & \\
\hline $\mathrm{Aa} 2$ & $-0.048^{*}$ & $0.098^{* *}$ & & \\
\hline Aa3 & $0.409^{* *}$ & $0.095^{* *}$ & & \\
\hline A1 & $0.354^{* *}$ & $-0.143^{* *}$ & & \\
\hline $\mathrm{A} 2$ & $0.148^{* *}$ & $-0.203^{* *}$ & & \\
\hline Relative wealth & $-0.726^{* *}$ & $0.068^{* *}$ & & \\
\hline Firm profitability & $-0.303^{* *}$ & $0.134^{* *}$ & & \\
\hline Firm size & 0.039 & 0.027 & & \\
\hline US unemployment rate & & $-0.257^{* *}$ & & \\
\hline $\begin{array}{l}\text { Japan job-offers-to-applicants } \\
\text { ratio }\end{array}$ & $-0.257^{* *}$ & & & \\
\hline Single downgrade & & & $-0.053^{*}$ & $-0.179^{* *}$ \\
\hline Double downgrade & & & $-0.449^{* *}$ & $-0.312^{* *}$ \\
\hline Change in relative wealth & & & $-0.588^{* *}$ & $0.265^{* *}$ \\
\hline Change in firm profitability & & & $-0.174^{* *}$ & $0.173^{* *}$ \\
\hline Change in firm size & & & $-0.239^{* *}$ & $0.395^{* *}$ \\
\hline $\begin{array}{l}\text { Change in US unemployment } \\
\text { rate }\end{array}$ & & & & $-0.366^{* *}$ \\
\hline $\begin{array}{l}\text { Change in Japan job-offers-to } \\
\text {-applicants ratio }\end{array}$ & & & $-0.366^{* *}$ & \\
\hline
\end{tabular}

with only one of the business cycle variables and without the business cycle variables. Table 2 shows the results of the ZIP regressions and Table 3 shows the results of the ZINB regressions. From the two tables, we note that both real cycle variables are significant in all the regressions despite the fact that these results are not justified by economic theory. This is consistent with Moulton's (1990) contention that the standard errors of the two macroeconomic are biased downward because they are highly correlated with firm-level variables in which the disturbance terms are likely correlated within groups. Therefore, the relationship could be spurious. We also note that when we exclude the level and the change in US unemployment rate, the coefficients of the firm-level regressors become significant. These results are consistent with regressions with the problem of multicollinearity because it biases the standard errors of the firm-level variables 
Table 2. Estimates of the Zero-Inflated Poisson (ZIP) Model for All Firms

\begin{tabular}{|c|c|c|c|c|}
\hline \multicolumn{5}{|l|}{ Variable } \\
\hline \multicolumn{5}{|c|}{ Dependent variable: rate of $F D I_{i}$ (conditional on firm i likely to invest in FDI) } \\
\hline Constant & $\begin{array}{c}0.044 \\
(0.072)\end{array}$ & $0.158^{* *}$ & $\begin{array}{c}0.059 \\
(0.068)\end{array}$ & $0.215^{* * *}$ \\
\hline \multirow{2}{*}{ Single downgrade } & $\begin{array}{l}(0.0 / 2) \\
-0.012\end{array}$ & $(0.063)$ & $\begin{array}{c}(0.008) \\
0.006\end{array}$ & $\begin{array}{l}(0.000) \\
-0.105\end{array}$ \\
\hline & $(0.100)$ & $\begin{array}{l}-0.120 \\
(0.093)\end{array}$ & $(0.096)$ & $(0.093)$ \\
\hline \multirow[t]{2}{*}{ Multiple downgrades } & $-0.303^{*}$ & $(0.093)$ & $-0.471^{* * * *}$ & $-0.703^{* * *}$ \\
\hline & $(0.177)$ & $\begin{array}{l}-0.409 \\
(0.177)\end{array}$ & $(0.167)$ & $(0.164)$ \\
\hline \multirow[t]{2}{*}{ Change in relative wealth } & 0.051 & $(0.1 / 7)$ & $0.224^{* *}$ & $0.246^{* *}$ \\
\hline & $(0.133)$ & -0.006 & $(0.112)$ & $(0.109)$ \\
\hline \multirow[t]{2}{*}{ Change in profitability } & -2.465 & $\begin{array}{c}(0.133) \\
1.058\end{array}$ & -2.913 & 1.671 \\
\hline & $(3.237)$ & $\begin{array}{l}1.058 \\
(3.103)\end{array}$ & $(3.276)$ & $(3.164)$ \\
\hline \multirow[t]{2}{*}{ Change in firm size } & -0.319 & $\begin{array}{c}(3.103) \\
0.183\end{array}$ & -0.278 & 0.410 \\
\hline & $(0.380)$ & $(0.366)$ & $(0.381)$ & $(0.375)$ \\
\hline \multirow{2}{*}{$\begin{array}{l}\text { Change in US unemployment rate } \\
\text { Change in Japanese job-offers-to- } \\
\text { applicants ratio }\end{array}$} & $-0.216^{* *}$ & $-0.294^{* * *}$ & & \\
\hline & $\begin{array}{l}(0.092) \\
0.804^{* * *} \\
(0.190)\end{array}$ & $\begin{array}{c}-0.294 \\
(0.081)\end{array}$ & $\begin{array}{c}0.973^{* * *} \\
(0.179)\end{array}$ & \\
\hline \multicolumn{5}{|c|}{ Dependent variable: Probability that firm $\mathrm{i}$ is likely to invest in FDI $\left(1-P_{i}\right)$} \\
\hline Constant & $\begin{array}{c}-7.589^{* * *} \\
(1.984)\end{array}$ & $\begin{array}{c}-5.699^{* * *} \\
(1.621)\end{array}$ & $\begin{array}{c}-7.654^{* * *} \\
(1.854)\end{array}$ & $\begin{array}{c}-5.540^{* * *} \\
(1.600)\end{array}$ \\
\hline \multirow[t]{2}{*}{ Aa1 } & $-0.408^{*}$ & $-0.420^{* *}$ & $-0.448^{*}$ & $-0.548^{* * * *}$ \\
\hline & $(0.240)$ & $(0.212)$ & $(0.230)$ & $(0.202)$ \\
\hline \multirow[t]{2}{*}{ Aa2 } & 0.084 & 0.102 & 0.068 & 0.054 \\
\hline & $(0.423)$ & $(0.435)$ & $(0.418)$ & $(0.433)$ \\
\hline \multirow[t]{2}{*}{$\mathrm{Aa} 3$} & -0.257 & $-0.402^{*}$ & -0.300 & $-0.593^{* * * *}$ \\
\hline & $(0.261)$ & $(0.227)$ & $(0.237)$ & $(0.213)$ \\
\hline \multirow[t]{2}{*}{ A1 } & -0.223 & -0.317 & -0.322 & $-0.580^{* *}$ \\
\hline & $(0.348)$ & $(0.303)$ & $(0.314)$ & $(0.278)$ \\
\hline \multirow[t]{2}{*}{ A2 } & -0.528 & -0.607 & -0.521 & $-0.720^{*}$ \\
\hline & $(0.452)$ & $(0.405)$ & $(0.454)$ & (0.399) \\
\hline \multirow[t]{2}{*}{ Relative wealth } & 0.151 & 0.301 & 0.233 & $0.541^{* * *}$ \\
\hline & $(0.263)$ & $(0.253)$ & $(0.240)$ & $(0.223)$ \\
\hline \multirow[t]{2}{*}{ Firm profitability } & $9.110^{* * *}$ & 6.221 & $9.399^{* * *}$ & 5.687 \\
\hline & (4.311) & (4.098) & $(4.258)$ & (3.966) \\
\hline \multirow[t]{2}{*}{ Firm size } & $0.771^{* * *}$ & $0.724^{* * *}$ & $0.769^{* * *}$ & $0.704^{* * * *}$ \\
\hline & $(0.072)$ & $(0.067)$ & $(0.071)$ & $(0.064)$ \\
\hline \multirow{2}{*}{ US unemployment rate } & -0.138 & $-0.265^{*}$ & & \\
\hline & $(0.193)$ & $(0.150)$ & & \\
\hline Japanese job-offers-to-applicants & -0.262 & & -0.406 & \\
\hline ratio & $(0.318)$ & & $(0.255)$ & \\
\hline Number of firms & 317 & 317 & 317 & 317 \\
\hline Log-likelihood & -1920.72 & -1929.82 & -1924.91 & -1939.72 \\
\hline Vuong Statistic & $7.13^{* * *}$ & $7.35^{* * *}$ & $7.22^{* * *}$ & $7.42^{* * *}$ \\
\hline
\end{tabular}

Notes: Relative wealth is the log of the firm's market value plus the log of the US dollar-Japanese yen exchange rate minus the log of the S\&P 500 index. Firm profitability is the ratio of the firm's profit to assets. Firm size is the log of the firm's assets deflated by the wholesale price index. The probability of the firm intending to invest in the United States equals one minus the probability of a firm not intending to invest in the United States. Numbers in brackets are the standard errors. The US unemployment rate is from the International Financial Statistics and the Japan job-offersto-application ratio is from the Monthly Report of Employment Security Business by the Employment Security Bureau, Japanese Ministry of Labor. The Vuong test has a null that the Poisson model cannot be rejected in favor of the ZIP model and an alternative that the Poisson model is rejected in favor of the ZIP model. The Vuong statistic has an asymptotic normal distribution. ${ }^{*}, * *$, and ${ }^{* * *}$ refer to $10 \%, 5 \%$ and $1 \%$ levels of significance respectively 
Table 3. Estimates of the Zero-Inflated Negative Binomial (ZINB) Model for All Firms

\begin{tabular}{|c|c|c|c|c|}
\hline \multicolumn{5}{|l|}{ Variable } \\
\hline \multicolumn{5}{|c|}{ Dependent variable: rate of $F D I_{i}$ (conditional on firm i likely to invest in FDI) } \\
\hline Constant & $\begin{array}{c}-0.252^{* * *} \\
(0.086)\end{array}$ & $\begin{array}{l}-0.143^{*} \\
(0.081)\end{array}$ & $\begin{array}{c}-0.234^{* * *} \\
(0.083)\end{array}$ & $\begin{array}{l}-0.087 \\
(0.081)\end{array}$ \\
\hline Single downgrade & -0.029 & -0.133 & 0.002 & -0.110 \\
\hline Multiple downgrades & $\begin{array}{l}(0.114) \\
-0.270\end{array}$ & $-0.404^{* * *}$ & $\begin{array}{l}(0.112) \\
-0.457^{* *}\end{array}$ & $\begin{array}{l}(0.110) \\
-0.727^{* * *} \\
(0.177)\end{array}$ \\
\hline Change in relative wealth & $\begin{array}{c}(0.060) \\
(0.161)\end{array}$ & $\begin{array}{c}(0.194) \\
0.000 \\
(0.161)\end{array}$ & $\begin{array}{c}(0.181) \\
0.258^{*} \\
(0.138)\end{array}$ & $\begin{array}{l}0.267^{* * *} \\
(0.133)\end{array}$ \\
\hline Change in profitability & $\begin{array}{l}-3.786 \\
(3.818)\end{array}$ & $\begin{array}{c}0.051 \\
(3.755)\end{array}$ & $\begin{array}{l}-4.026 \\
(3.819)\end{array}$ & $\begin{array}{l}1.314 \\
(3.833)\end{array}$ \\
\hline Change in firm size & $\begin{array}{l}-0.357 \\
(0.455)\end{array}$ & $\begin{array}{l}0.217 \\
(0.435)\end{array}$ & $\begin{array}{l}-0.315 \\
(0.456)\end{array}$ & $\begin{array}{l}0.488 \\
(0.436)\end{array}$ \\
\hline Change in US unemployment rate & $\begin{array}{l}-0.239^{* *} \\
(0.105)\end{array}$ & $\begin{array}{c}-0.317^{* * *} \\
(0.094)\end{array}$ & & \\
\hline $\begin{array}{l}\text { Change in Japanese job offers- } \\
\text { to-applicants ratio }\end{array}$ & $\begin{array}{l}0.889^{* * * *} \\
(0.214)\end{array}$ & & $\begin{array}{l}1.082^{* * *} \\
(0.200)\end{array}$ & \\
\hline \multicolumn{5}{|c|}{ Dependent variable: Probability that firm $i$ is likely to invest in FDI $\left(1-P_{i}\right)$} \\
\hline Constant & $\begin{array}{c}-10.915^{* * *} \\
(2.941)\end{array}$ & $\begin{array}{l}-7.894^{* * * *} \\
(2.529)\end{array}$ & $\begin{array}{l}-10.935^{* * *} \\
(2.804)\end{array}$ & $\begin{array}{l}-7.449^{* * *} \\
(2.450)\end{array}$ \\
\hline Aal & $\begin{array}{l}-0.612 \\
(0.382)\end{array}$ & $\begin{array}{l}-0.648^{* *} \\
(0.330)\end{array}$ & $\begin{array}{l}-0.648^{*} \\
(0.357)\end{array}$ & $\begin{array}{l}-0.774^{* *} \\
(0.304)\end{array}$ \\
\hline Aa2 & $\begin{array}{c}0.230 \\
(0.719)\end{array}$ & $\begin{array}{c}0.293 \\
(0.776)\end{array}$ & $\begin{array}{c}0.191 \\
(0.688)\end{array}$ & $\begin{array}{l}0.226 \\
(0.759)\end{array}$ \\
\hline $\mathrm{Aa} 3$ & $\begin{array}{l}-0.258 \\
(0.398)\end{array}$ & $\begin{array}{l}-0.472 \\
(0.335)\end{array}$ & $\begin{array}{l}-0.351 \\
(0.351)\end{array}$ & $\begin{array}{l}-0.769^{* * *} \\
(0.307)\end{array}$ \\
\hline A1 & $\begin{array}{l}-0.225 \\
(0.516)\end{array}$ & $\begin{array}{l}-0.415 \\
(0.436)\end{array}$ & $\begin{array}{l}-0 . .429 \\
(0.462)\end{array}$ & $\begin{array}{l}-0.834^{* *} \\
(0.399)\end{array}$ \\
\hline A2 & $\begin{array}{l}-0.524 \\
(0.641)\end{array}$ & $\begin{array}{l}-0.743 \\
(0.557)\end{array}$ & $\begin{array}{l}-0.543 \\
(0.649)\end{array}$ & $\begin{array}{l}-0.936^{*} \\
(0.553)\end{array}$ \\
\hline Relative wealth & $\begin{array}{l}-0.076 \\
(0.399)\end{array}$ & $\begin{array}{c}0.158 \\
(0.387)\end{array}$ & $\begin{array}{c}0.099 \\
(0.347)\end{array}$ & $\begin{array}{l}0.574^{* *} \\
(0.327)\end{array}$ \\
\hline Firm profitability & $\begin{array}{l}13.734^{* *} \\
(6.640)\end{array}$ & $\begin{array}{l}8.905 \\
(6.249)\end{array}$ & $\begin{array}{l}13.659^{* *} \\
(6.356)\end{array}$ & $\begin{array}{c}7.107 \\
(5.835)\end{array}$ \\
\hline Firm size & $\begin{array}{l}1.063^{* * * *} \\
(0.123)\end{array}$ & $\begin{array}{l}1.000^{* * * *} \\
(0.118)\end{array}$ & $\begin{array}{l}1.036^{* * *} \\
(0.117)\end{array}$ & $\begin{array}{l}0.945^{* * *} \\
(0.109)\end{array}$ \\
\hline US unemployment rate & $\begin{array}{l}-0.277 \\
(0.277)\end{array}$ & $\begin{array}{l}-0.466^{* *} \\
(0.222)\end{array}$ & & \\
\hline $\begin{array}{l}\text { Japanese job offers-to-applicants } \\
\text { ratio }\end{array}$ & $\begin{array}{l}-0.280 \\
(0.495)\end{array}$ & & $\begin{array}{l}-0.436 \\
(0.397)\end{array}$ & \\
\hline Number of firms & 317 & 317 & 317 & 317 \\
\hline Log-likelihood & -1857.93 & -1866.15 & -1862.49 & -1876.35 \\
\hline Likelihood ratio test of & $125.58^{* * *}$ & $127.34^{* * *}$ & $124.84^{* * * *}$ & $126.75^{* * *}$ \\
\hline
\end{tabular}

Notes: Relative wealth is the log of the firm's market value plus the log of the US dollar-Japanese yen exchange rate minus the $\log$ of the S\&P 500 index. Firm profitability is the ratio of the firm's profit to assets. Firm size is the $\log$ of the firm's assets deflated by the wholesale price index. The US unemployment rate is from the International Financial Statistics and the Japan job-offers-to-application ratio is from the Monthly Report of Employment Security Business by the Employment Security Bureau, Japanese Ministry of Labor. The probability of the firm intending to invest in the United States equals one minus the probability of a firm not intending to invest in the United States. Numbers in brackets are the standard errors. The likelihood ratio test of $\alpha=0$, has a null hypothesis that the underlying distribution is Poisson and an alternative hypothesis that the underlying distribution is negative binomial. *, ${ }^{* *}$, and ${ }^{* * *}$ refer to $10 \%, 5 \%$ and $1 \%$ levels of significance respectively 
upward making them insignificant. Researchers often deal with multicollinearity by removing variables causing the problem. This could also cause omitted variables bias if the removed variables are supposed to be included in the regression. In our case, however, there is no good reason why firm-specific assets become more or less attractive during economics upturns or downturns. Economic theory does not suggest that business cycle variables should be included regression. Hence, we exclude business cycle variables. ${ }^{18}$

Tables 4 shows the regression estimates, the log-likelihood and the Vuong statistics of the zero-inflated Poisson (ZIP) model for samples with all firms and firms with the lowest $80 \%$ and the highest $20 \%$ of bonds-to-liabilities ratio and firms with FDI projects for multiple years. We split our sample of firms according to their bonds-to-liabilities ratios because firms that issue more bonds could be less affected by rating downgrades of their main banks. We use the Vuong statistic as a measure of the relevance of accounting for excess zeros in our sample. The Vuong test has a null that the Poisson model cannot be rejected in favor of the ZIP model and an alternative that the Poisson model is reject in favor of the ZIP model. For the full sample and the sub-samples of firms, the Vuong statistics reject the Poisson model in favor of the ZIP model at the $1 \%$ level of significance.

Table 5 shows the regression and log-likelihood estimates, and the score test statistics of the zero-inflated negative binomial (ZINB) model for our full sample and sub-samples of firms. We use the score test, as developed by Ridout, Hinde and Demétrio (2001), to determine whether the Poisson or the negative binomial distribution is the more appropriate distribution of FDI projects for firms with intention to invest in United States. The score test has a null hypothesis that the conditional distribution of FDI projects is Poisson against an alternative hypothesis that the conditional distribution is negative binomial. The score test statistics show that the null of Poisson distribution can be rejected in favor of the negative binomial distribution for all firms in our full sample and for sub-samples of firms with the lowest $80 \%$ of bonds-to-liabilities ratio and of firms with multi-year FDI. However, the null hypothesis cannot be rejected in favor alternative hypothesis for firms with the highest $20 \%$ of bonds-to-liabilities ratio. The results show that the ZINB model is more appropriate for our full sample and sub-samples of firms with the lowest $80 \%$ of bonds-to-liabilities ratio and of firms with multi-year FDI but the ZIP model is more appropriate for the sub-sample of firms with the highest

\footnotetext{
${ }^{18}$ Please refer to Chapter 10 of Gujarati (2003) for a discussion of multicollinearity in regressions.
} 
Table 4. Estimates of the Zero-Inflated Poisson (ZIP) Model

\begin{tabular}{|c|c|c|c|c|}
\hline Variable & All Firms & $\begin{array}{l}\text { Lowest } 80 \% \text { of all } \\
\text { firms with bonds- } \\
\text { to- liabilities ratio }\end{array}$ & $\begin{array}{l}\text { Highest } 20 \% \text { of all } \\
\text { firms with bonds-to- } \\
\text { liabilities ratio }\end{array}$ & $\begin{array}{l}\text { Multi-year } \\
\text { FDI Firms }\end{array}$ \\
\hline \multicolumn{5}{|c|}{ Dependent variable: rate of $F D I_{i}$ (conditional on firm $\mathrm{i}$ intending to invest in FDI) } \\
\hline Constant & $\begin{array}{c}0.215^{* * *} \\
(0.060)\end{array}$ & $\begin{array}{l}0.292^{* * *} \\
(0.049)\end{array}$ & $\begin{array}{c}-0.393^{* * *} \\
(0.165)\end{array}$ & $\begin{array}{c}0.363^{* * *} \\
(0.062)\end{array}$ \\
\hline Single downgrade & $\begin{array}{l}-0.105 \\
(0.093)\end{array}$ & $\begin{array}{l}-0.110 \\
(0.081)\end{array}$ & $\begin{array}{l}-0.151 \\
(0.289)\end{array}$ & $\begin{array}{l}-0.127 \\
(0.096)\end{array}$ \\
\hline Multiple downgrades & $\begin{array}{c}-0.703^{* * * *} \\
(0.164)\end{array}$ & $\begin{array}{c}-0.704^{* * * *} \\
(0.184)\end{array}$ & $\begin{array}{l}-0.850^{*} \\
(0.483)\end{array}$ & $\begin{array}{c}-0.638^{* *} \\
(0.171)\end{array}$ \\
\hline Change in relative wealth & $\begin{array}{l}0.246^{* *} \\
(0.109)\end{array}$ & $\begin{array}{l}0.261^{* * * *} \\
(0.090)\end{array}$ & $\begin{array}{l}-0.124 \\
(0.371)\end{array}$ & $\begin{array}{l}0.213^{*} \\
(0.109)\end{array}$ \\
\hline Change in profitability & $\begin{array}{c}1.671 \\
(3.164)\end{array}$ & $\begin{array}{l}1.315 \\
(3.766)\end{array}$ & $\begin{array}{c}1.589 \\
(17.165)\end{array}$ & $\begin{array}{l}6.933^{* *} \\
(3.250)\end{array}$ \\
\hline Change in firm size & $\begin{array}{c}0.410 \\
(0.375)\end{array}$ & $\begin{array}{l}0.668^{* *} \\
(0.339)\end{array}$ & $\begin{array}{c}0.592 \\
(1.048)\end{array}$ & $\begin{array}{c}0.440 \\
(0.373)\end{array}$ \\
\hline \multicolumn{5}{|c|}{ Dependent variable: Probability that firm i intending to invest in FDI $\left(1-P_{i}\right)$} \\
\hline Constant & $\begin{array}{c}-5.540^{* * *} \\
(1.600)\end{array}$ & $\begin{array}{c}-6.925^{* * *} \\
(1.720)\end{array}$ & $\begin{array}{c}9.389 \\
(6.679)\end{array}$ & $\begin{array}{l}-3.866^{*} \\
(2.264)\end{array}$ \\
\hline Aa1 & $\begin{array}{c}-0.548^{* * * *} \\
(0.202)\end{array}$ & $\begin{array}{l}-0.395^{*} \\
(0.212)\end{array}$ & $\begin{array}{l}-1.349 \\
(1.018)\end{array}$ & $\begin{array}{c}-0.710^{* * *} \\
(0.279)\end{array}$ \\
\hline $\mathrm{Aa} 2$ & $\begin{array}{c}0.054 \\
(0.433)\end{array}$ & $\begin{array}{l}-0.129 \\
(0.448)\end{array}$ & $\begin{array}{c}0.327 \\
(1.850)\end{array}$ & $\begin{array}{l}-0.126 \\
(0.540)\end{array}$ \\
\hline $\mathrm{Aa} 3$ & $\begin{array}{c}-0.593^{* * * *} \\
(0.213)\end{array}$ & $\begin{array}{l}-0.384 \\
(0.227)\end{array}$ & $\begin{array}{l}-1.415 \\
(0.925)\end{array}$ & $\begin{array}{c}-0.915^{* * * *} \\
(0.294)\end{array}$ \\
\hline A1 & $\begin{array}{c}-0.580^{* * *} \\
(0.278)\end{array}$ & $\begin{array}{l}-0.426 \\
(0.296)\end{array}$ & $\begin{array}{l}-1.009 \\
(1.106)\end{array}$ & $\begin{array}{l}-0.718^{*} \\
(0.367)\end{array}$ \\
\hline A2 & $\begin{array}{l}-0.720^{*} \\
(0.399)\end{array}$ & $\begin{array}{l}-0.780^{*} \\
(0.421)\end{array}$ & $\begin{array}{l}-0.221 \\
(1.491)\end{array}$ & $\begin{array}{c}-1.328^{* * * *} \\
(0.484)\end{array}$ \\
\hline Relative wealth & $\begin{array}{l}0.541^{* *} \\
(0.223)\end{array}$ & $\begin{array}{c}0.362 \\
(0.233)\end{array}$ & $\begin{array}{l}2.703^{* *} \\
(1.101)\end{array}$ & $\begin{array}{l}0.628^{* *} \\
(0.309)\end{array}$ \\
\hline Firm profitability & $\begin{array}{c}5.687 \\
(3.966)\end{array}$ & $\begin{array}{l}8.568^{* *} \\
(4.269)\end{array}$ & $\begin{array}{l}-11.563 \\
(16.673)\end{array}$ & $\begin{array}{c}0.210 \\
(4.967)\end{array}$ \\
\hline Firm size & $\begin{array}{c}0.704^{* * *} \\
(0.064)\end{array}$ & $\begin{array}{l}0.709^{* * * *} \\
(0.072)\end{array}$ & $\begin{array}{l}0.694^{* *} \\
(0.276)\end{array}$ & $\begin{array}{c}0.668^{* * *} \\
(0.099)\end{array}$ \\
\hline Number of firms & 317 & 254 & 63 & 185 \\
\hline Log-likelihood & -1939.12 & -1610.82 & -304.29 & -1293.80 \\
\hline Vuong Statistic & $20.76^{* * *}$ & $19.88^{* * *}$ & $5.73^{* * *}$ & $10.74^{* * *}$ \\
\hline
\end{tabular}

Notes: Relative wealth is the log of the firm's market value plus the log of the US dollar-Japanese yen exchange rate minus the log of the S\&P 500 index. Firm profitability is the ratio of the firm's profit to assets. Firm size is the log of the firm's assets deflated by the wholesale price index. The probability of the firm with intention to invest in the United States equals one minus the probability of a firm without the intention to invest in the United States. Numbers in brackets are the standard errors. The Vuong test has a null that the Poisson model cannot be rejected in favor of the ZIP model and an alternative that the Poisson model is rejected in favor of the ZIP model. The Vuong statistic has an asymptotic normal distribution. ${ }^{*}, * *$ and $^{* * *}$ refer to $10 \%, 5 \%$ and $1 \%$ levels of significance respectively. 
Table 5. Estimates of the Zero-Inflated Negative Binomial (ZINB) Model

\begin{tabular}{|c|c|c|c|c|}
\hline Variable & All Firms & $\begin{array}{c}\text { Lowest } 80 \% \text { of } \\
\text { all firms with bonds-to- } \\
\text { liabilities ratio }\end{array}$ & $\begin{array}{l}\text { Highest } 20 \% \text { of } \\
\text { all firms with bonds } \\
\text {-to- liabilities ratio }\end{array}$ & $\begin{array}{l}\text { Multi-year } \\
\text { FDI Firms }\end{array}$ \\
\hline \multicolumn{5}{|c|}{ Dependent variable: rate of $F D I_{i}$ (conditional on firm i intending to invest in FDI) } \\
\hline Constant & $\begin{array}{l}-0.087 \\
(0.081)\end{array}$ & $\begin{array}{c}0.281 \\
(0.085)\end{array}$ & $\begin{array}{l}-0.393 \\
(0.195)\end{array}$ & $\begin{array}{c}0.358 \\
(0.078)\end{array}$ \\
\hline Single downgrade & $\begin{array}{l}-0.110 \\
(0.110)\end{array}$ & $\begin{array}{l}-0.099 \\
(0.113)\end{array}$ & $\begin{array}{l}-0.153 \\
(0.263)\end{array}$ & $\begin{array}{l}-0.119 \\
(0.114)\end{array}$ \\
\hline Multiple downgrades & $\begin{array}{c}-0.727^{* * *} \\
(0.177)\end{array}$ & $\begin{array}{c}-0.695^{* * *} \\
(0.190)\end{array}$ & $\begin{array}{l}-0.851^{*} \\
(0.515)\end{array}$ & $\begin{array}{l}-0.626^{* *} \\
(0.188)\end{array}$ \\
\hline Change in relative wealth & $\begin{array}{l}0.267^{* * *} \\
(0.133)\end{array}$ & $\begin{array}{l}0.270^{* * *} \\
(0.137)\end{array}$ & $\begin{array}{l}-0.124 \\
(0.355)\end{array}$ & $\begin{array}{c}0.220 \\
(0.147)\end{array}$ \\
\hline Change in profitability & $\begin{array}{c}1.314 \\
(3.833)\end{array}$ & $\begin{array}{c}1.253 \\
(3.660)\end{array}$ & $\begin{array}{c}1.484 \\
(9.641)\end{array}$ & $\begin{array}{c}7.773 \\
(4.936)\end{array}$ \\
\hline Change in firm size & $\begin{array}{c}0.488 \\
(0.436)\end{array}$ & $\begin{array}{c}0.764 \\
(0.745)\end{array}$ & $\begin{array}{c}0.592 \\
(1.065)\end{array}$ & $\begin{array}{c}0.470 \\
(0.515)\end{array}$ \\
\hline \multicolumn{5}{|c|}{ Dependent variable: Probability that firm i intending to invest in FDI $\left(1-P_{i}\right)$} \\
\hline Constant & $\begin{array}{l}-3.866^{*} \\
(2.264)\end{array}$ & $\begin{array}{l}-6.945 \\
(1.739)\end{array}$ & $\begin{array}{c}9.396 \\
(4.844)\end{array}$ & $\begin{array}{l}-3.870 \\
(2.319)\end{array}$ \\
\hline Aa1 & $\begin{array}{l}-0.710^{* * *} \\
(0.279)\end{array}$ & $\begin{array}{l}-0.394^{*} \\
(0.222)\end{array}$ & $\begin{array}{c}-1.346^{* * *} \\
(0.596)\end{array}$ & $\begin{array}{l}-0.707^{* *} \\
(0.276)\end{array}$ \\
\hline $\mathrm{Aa} 2$ & $\begin{array}{l}-0.126 \\
(0.540)\end{array}$ & $\begin{array}{l}-0.128 \\
(0.463)\end{array}$ & $\begin{array}{c}0.329 \\
(0.947)\end{array}$ & $\begin{array}{l}-0.137 \\
(0.511)\end{array}$ \\
\hline Aa3 & $\begin{array}{c}-0.915^{* * * *} \\
(0.294)\end{array}$ & $\begin{array}{l}-0.382 \\
(0.241)\end{array}$ & $\begin{array}{c}-1.412^{* *} \\
(0.620)\end{array}$ & $\begin{array}{l}-0.914^{* * * *} \\
(0.293)\end{array}$ \\
\hline A1 & $\begin{array}{l}-0.718^{*} \\
(0.367)\end{array}$ & $\begin{array}{l}-0.426 \\
(0.310)\end{array}$ & $\begin{array}{l}-1.003 \\
(0.813)\end{array}$ & $\begin{array}{l}-0.720^{*} \\
(0.368)\end{array}$ \\
\hline A2 & $\begin{array}{c}-1.328^{* * * *} \\
(0.484)\end{array}$ & $\begin{array}{l}-0.781^{*} \\
(0.459)\end{array}$ & $\begin{array}{l}-0.214 \\
(1.136)\end{array}$ & $\begin{array}{c}-1.333^{* * * *} \\
(0.495)\end{array}$ \\
\hline Relative wealth & $\begin{array}{l}0.628^{* *} \\
(0.309)\end{array}$ & $\begin{array}{c}0.359 \\
(0.246)\end{array}$ & $\begin{array}{l}2.705^{* * *} \\
(0.739)\end{array}$ & $\begin{array}{l}0.625^{* *} \\
(0.316)\end{array}$ \\
\hline Firm profitability & $\begin{array}{c}0.210 \\
(4.967)\end{array}$ & $\begin{array}{l}8.554^{*} \\
(4.467)\end{array}$ & $\begin{array}{l}-11.490 \\
(13.854)\end{array}$ & $\begin{array}{l}-0.492 \\
(5.325)\end{array}$ \\
\hline Firm size & $\begin{array}{c}0.668^{* * *} \\
(0.099\end{array}$ & $\begin{array}{l}0.709^{* * * *} \\
(0.064)\end{array}$ & $\begin{array}{l}0.695^{* * *} \\
(0.209)\end{array}$ & $\begin{array}{l}0.667^{* * * *} \\
(0.084)\end{array}$ \\
\hline Number of firms & 317 & 254 & 63 & 185 \\
\hline Log-likelihood & -1894.98 & -1568.62 & -304.00 & -1436.57 \\
\hline Score test statistic & $24.05^{* * *}$ & $22.37^{* * *}$ & 1.40 & $20.30^{* * *}$ \\
\hline
\end{tabular}

Notes: Relative wealth is the log of the firm's market value plus the log of the US dollar-Japanese yen exchange rate minus the $\log$ of the S\&P 500 index. Firm profitability is the ratio of the firm's profit to assets. Firm size is the $\log$ of the firm's assets deflated by the wholesale price index. The probability that a firm has intention to invest in the United States equals one minus the probability that a firm has no intention to invest in the United States. Numbers in brackets are the standard errors. The score test, as developed by Ridout, Hinde and Demétrio (2001), has a null hypothesis that the underlying distribution is Poisson and an alternative hypothesis that the underlying distribution is negative binomial. ${ }^{*}, * *$, and ${ }^{* * * *}$ refer to $10 \%, 5 \%$ and $1 \%$ levels of significance respectively 
$20 \%$ of bonds-to-liabilities ratio.

For our full sample, the estimates of the ZINB model show that the probability that a firm has the intention to invest in the United States $\left(1-P_{i}\right)$ is negatively related to the dummy variables for the ratings of Aa1, Aa3, A1 and A2 at the $10 \%$ and higher levels of significance. Hence, a firm is less likely to have the intention to invest in the United States when the rating of its main bank is lower than a rating of Aaa, and has a lower rate of FDI. Furthermore, the probability that a firm has intention to invest in the United States is positively related to the firm's relative wealth and size at the $5 \%$ or higher levels of significance. Therefore, large firms and firms with high relative wealth are more likely to have the intention to invest in the United States, and have higher rates of FDI. These relationships also hold for the sub-samples of firms with the lowest $80 \%$ of bonds-to-liabilities ratio and of firms with multi-year FDI. The results are quite robust to splitting the full sample into sub-sample of firms with the lowest $80 \%$ of bonds-to-liabilities ratio and firms with multi-year FDI.

As shown in estimates of the ZIP model for the firms with the highest $20 \%$ of bonds-to-liabilities ratio, the probability that a firm has intention to invest in the United States is strongly and positively related only with firm size and relative wealth. While these results are similar to those mentioned above for the full sample and the other sub-samples, the effect of relative access to credit on the probability that a firm has intention to undertake FDI is insignificant even at the $10 \%$ significant level for firms with the highest $20 \%$ of bonds-to-liabilities ratio. Hence, for this sub-sample of firms, the probability of a firm's intention to undertake FDI does not depend on the financial health of the firm's main bank.

For our full sample, the estimates of ZINB model show that the conditional rate of FDI projects for a firm with intention to invest in the United States $\left(\lambda_{i}\right)$ is negatively related to multiple downgrades of a firm's main bank at the $1 \%$ level of significance. This relationship is confirmed by the two other ZINB models for firms with the lowest $80 \%$ of bonds-to-liabilities ratio and for firms with multi-year FDI, as well as the ZIP model for the firms with the highest $20 \%$ of bonds-toliabilities ratio. This implies that with a severe deterioration in the financial health of firm's main bank, the firm has a lower rate of FDI projects.

For our full sample, the estimates of ZINB model show that the conditional rate of FDI projects for a firm with intention to invest in the United States $\left(\lambda_{i}\right)$ is positively related to the change in the firm's relative wealth at the $5 \%$ level of significance. It suggests that with an increase in firm's relative wealth, the firm has 
a higher rate of FDI projects. The result also holds under the ZINB model for firms with the lowest $80 \%$ of bonds-to-liabilities ratio. However, the same result does not hold in the ZINB model for firms with multi-year FDI and in the ZIP model for the firms with the highest $20 \%$ of bonds-to-liabilities.

In summary, our results, which show the significant and positive effect of firm size on $1-P_{i}$ and the significant and negative effect of multiple downgrades of the firm's main bank on $\lambda_{i}$, are robust to splitting our full sample according to the bonds-to-liabilities ratio and single- or multi-year FDI of Japanese firms. Our results also show that for the full sample or the split samples, the single downgrade of the firm's main bank and the change in the firm profitability have no significant effect on the rate of FDI projects for a firm.

\section{Conclusions}

We examine the impact of relative access on the Japanese firm's rate of FDI to the United States. We find that the firm's rate of FDI is significantly affected by the multiple rating downgrades of the firm's main bank. This result holds even after splitting the sample into firms with the lowest $80 \%$ and highest $20 \%$ of bonds-toliabilities ratio and firms that undertake FDI in multiple years. The effect is quite prevalent considering that eight of the 11 main banks in our study experienced multiple downgrades during our sample period. The prevalent effect of multiple downgrades on the firm's FDI is not surprising bearing in mind the close relationship between banks and firms in Japan. Klein, Peek and Rosengren mention anecdotal evidence that even large firms such as Toyota who has little need of a bank loan could still depend on their main banks for other banking functions. However, they are unable to confirm this using a logit regression for a sub-sample of firms with the highest $20 \%$ of bonds-to-liabilities ratio. In contrast, our results strongly confirm the impact of the financial crisis in Japan on the firm's rate of FDI even among firms with access to bond financing. Our evidence from the firm-level rate of Japanese FDI give stronger support Klein, Peek and Rosengren's (2002) relative access to credit hypothesis.

Unlike Klein, Peek and Rosengren's (2002) findings, we find that the change in relative wealth significantly affects the firm's rate of FDI for all firms in our sample and for firms with the lowest $80 \%$ of bonds-to-liabilities ratio. The difference in findings may be explained by Klein, Peek and Rosengren's use of aggregate data as a measure of relative wealth. In aggregation, heterogeneous firm 
effects could be lost, which in turn could lead to insignificant estimates. ${ }^{19}$ Hence, the evidence at the firm level shows some support to Froot and Stein (1991) contention that relative wealth affects the firm's rate of FDI.

Firm-level evidence shows that both relative wealth and relative access to credit could explain the large fluctuations in the Japanese FDI into the United States. The surge in Japanese FDI in the 1980s could be explained by the appreciation of the yen and the rise in stock prices while the large drop in Japanese FDI in the 1990s could be attributed to the stock market crash and the banking crisis in Japan. These explanations have important implications on the future trend in Japanese FDI because even if Japan has yet to recover from the banking crisis in the 1990s, a rise in the relative wealth of Japanese firms could also provide a stimulus for Japanese FDI not just in developed economies but in developing economies as well. ${ }^{20}$ For instance, in terms of yen, Japanese FDI into the United States rose by $51 \%$ from 1993 to 1997 . This was preceded by a rise in relative wealth of $27 \%$ from 1992 to 1994. The rise in Japanese FDI outflows to the rest of the world is even more impressive. It rose by $65 \%$ from 1993 to 1997 and, excluding OECD countries, it rose by $95 \%$ over the same period. ${ }^{21}$ While both Japanese FDI and relative wealth have trended downward from 1999 to 2005 , a sustained rise in relative wealth could reverse the decline in Japanese FDI outflows. ${ }^{22}$

Following Klein, Peek and Rosengren, our investigation is an empirical study of the impact of relative wealth and relative access to credit on the firm's rate of FDI. An interesting area of future research is to build a structural model to determine how relative wealth and relative access to credit affect the firm's rate of FDI. The theoretical relationships among the structural parameters will allow us to show the quantitative importance of relative wealth and relative credit in firm-level FDI. ${ }^{23}$

\footnotetext{
${ }^{19}$ It is possible that multicollinearity caused an upward bias in the standard error of the relative wealth coefficient in Klein, Peek and Rosengren's regressions.

${ }^{20}$ Peek (2004) discusses bank restructuring in Japan in the 1990s.

${ }^{21}$ Aggregate FDI data for Japan are from SOURCE OECD database "International direct investment by country, vol 2005." The yen-US dollar exchange rate and Japanese and US share prices are from International Financial Statistics (IFS), on-line, April 2006.

${ }^{22}$ The Wall Street Journal reports that for the fiscal year that ended March 31, 2006, the Topix rose 47\% while the Nikkei 225 rose 46\% (Miyazaki, J., (2006), Japan's corporate profits bode well for stock prices, Wall Street Journal, April 3, 2006). We confirm this using IFS data to calculate a $20 \%$ rise in relative wealth from January 2005 to January 2006.

${ }^{23} \mathrm{We}$ thank an anonymous referee for suggesting to us this interesting line of future research.
} 


\section{Acknowledgments}

We are grateful to an anonymous referee for helpful comments.

Received 29 October 2006, Accepted 27 February 2007

\section{References}

Aoki, M., Patrick, H., Sheard, P. (1994) The Japanese main bank system: an introductory overview, in The Japanese Main Bank System (Eds.) Aoki, M., Patrick, H., Oxford University Press, Oxford, pp. 3-50.

Blonigen, B. (1997) Firm-specific assets and the link between exchange rates and foreign direct investment, American Economic Review, 87, 447-465.

Caves, R. (1971) International corporations: the industrial economics of foreign investment, Economica, 38, 1-27.

Campa, J. (1993) Entry by foreign firms in the United States under exchange rate uncertainty, Review of Economics and Statistics, 75, 614-622.

Dunning, J. (1988) The eclectic paradigm of international production: a restatement and some possible extensions, Journal of International Business Studies, 19, 1-31.

Freund, D., Kniesner, T., LoSasso, A. (1999) Dealing with the common econometric problems of count data with excess zeros, endogenous treatment effects, and attrition bias, Economic Letters, 62, 7-12.

Froot, K., Stein, J. (1991) Exchange rates and foreign direct investment: an imperfect capital markets approach, Quarterly Journal of Economics, 106, 1191-1217.

Gibson, M. (1995) Can Bank Health Affect Investment? Evidence from Japan, Journal of Business, 68, 281-308.

Graham, E., Krugman, P. (1995) Foreign Direct Investment in the United States, Washington, D.C.: Institute for International Economics.

Greene, W. (1994) Accounting for excess zeros and sample selection in Poisson and negative binomial regression models, Working Paper EC-94-10, Department of Economics, New York University.

Greene, W. (2005) Econometric Analysis, New Jersey: Prentice-Hall.

Gujarati, D. (2003) Basic Econometrics, New York: McGraw Hill.

Horst, T. (1972) Firm and industry determinants of the decision to invest abroad: an empirical study, Review of Economics and Statistics, 54, 258-266.

Klein, M., Peek, J., Rosengren, E. (2002) Troubled banks, impaired foreign direct investment: the role of relative access to credit, American Economic Review, 92, 664-682.

Klein, M., Rosengren, E. (1994) The real exchange rate and foreign direct investment in the United States: relative wealth vs. relative wage effects, Journal of International Economics, 36, 373-389.

List, J. (2001) US county-level determinants of inbound FDI: evidence from a two step 
modified count data model, International Journal of Industrial Organization, 19, 953973.

Moulton, B. R. (1990) An illustration of a pitfall in estimating the effects of aggregate variables on micro unit, Review of Economics and Statistics, 72, 334-338.

Peek, J., (2004) The Japanese banking crisis: It's not over until the fat lady sings, manuscript, University of Kentucky.

Ridout, M., Hinde, J., Demétrio, C. (2001) A score test for testing a zero-inflated Poisson regression model against zero-inflated negative binomial alternatives, Biometrics, 57, 219-223.

Swenson, D. (2004) Foreign investment and the mediation of trade flows, Review of International Economics, 12, 609-629.

Tomlin, K., (2000) The effects of model specification on foreign direct investment models: An application of count data models, Southern Economic Journal, 67, 460-468. 